\title{
PENGARUH KEPEMIMPINAN TERHADAP KINERJA PEGAWAI BANK SINARMAS KCP METRO
}

\author{
Septian Hardhanto(1), Trisnowati Josiah ${ }^{(2)}$, Hujaimatul Fauziah ${ }^{(3)}$ \\ Fakultas Ekonomi Universitas Sang Bumi Ruwa Jurai \\ septian.hardhanto@gmail.com,trisnowati.josiah@fe.saburai.ac.id,hujaimatul.fauziah@fe.saburai.ac.id
}

\begin{abstract}
Abstrak. Kepemimpinan (leadership) dapat dikatakan sebagai cara dari seorang pemimpin (leader) dalam mengarahkan, mendorong dan mengatur seluruh unsur-unsur di dalam kelompok atau organisasinya untuk mencapai suatu tujuan organisasi yang diinginkan sehingga menghasilkan kinerja pegawai yang maksimal. Pemimpin harus berhubungan baik dengan siapa saja yang dipimpinnya. Dari ulasan latar belakang tersebut, maka penulis tertarik melakukan penelitian dengan judul "Pengaruh Kepemimpinan Terhadap Kinerja Pegawai Bank Sinarmas KCP Metro". Penelitian ini dilakukan di Bank Sinarmas KCP Metro, yang beralamatkan di Jl. Jenderal Sudirman No.872 Kelurahan Imopuro Kecamatan Metro Pusat, Kota Metro. Penelitian ini dilakukan selama bulan April - Juni 2018 di Kantor Bank Sinarmas KCP Metro. Dengan satuan penelitian pegawai tetap Bank Sinarmas KCP Metro. Hasil analisis dapat diinterpretasikan bahwa Kepemimpinan memiliki pengaruh yang besar yaitu sebesar $73.6 \%$ terhadap Kinerja pada Pegawai Bank Sinarmas KCP Metro. Dari pengolahan data juga didapatkan bahwa masih ada variabel lain tetapi tidak begitu besar pengaruhnya yang belum dimasukkan tetapi memiliki pengaruh pada Kinerja sebesar $26.4 \%$.
\end{abstract}

Kata kunci: Kepemimpinan, Kinerja, Pegawai, Pemimpin.

\section{PENDAHULUAN}

Pada sebuah organisasi atau perusahaan, kesuksesan atau kegagalan dalam pelaksanaan tugas dan penyelenggaraan, dipengaruhi oleh kepemimpinan. Melalui kepemimpinan dan didukung oleh kapasitas organisasi atau perusahaan yang memadai, maka penyelenggaraan fungsi organisasi atau perusahaan akan terwujud. Sebaliknya kelemahan kepemimpinan merupakan salah satu sebab keruntuhan kinerja suatu organisasi. Kepemimpinan merupakan cara seorang pemimpin dalam mengarahkan, mendorong, dan mengatur seluruh unsurunsur di dalam kelompok organisasi atau perusahaan untuk mencapi tujuan yang diinginkan sehingga menghasilkan kinerja pegawai yang maksimal.

Dengan meningkatnya kinerja pegawai maka tercapai hasil kerja seseorang atau pegawai dalam mewujudkan tujuan organisasi. Di setiap organisasi pasti ada pemimpin dan dipimpin. Pemimpin harus berhubungan baik dengan siapa saja yang dipimpinnya. Pemimpin harus mengenal dan mengetahui orang-orang yang ia pimpin dalam suatu organisasi. Pemimpin bertanggung jawab akan semua hal yang menyangkut organisasi perusahaan yang dijalankan. Organisasi akan berjalan dengan baik, ketika peran kepemimpinan dalam sebuah organisasi dijalankan dengan sebaik-baiknya dan penuh dengan tanggung jawab.

Namun sebaliknya jika peran kepemimpinan tidak dilaksanakan sesuai dengan aturan main yang ada maka akan timbul berbagai persoalan yang dapat menghambat atau mempengaruhi kinerja orang-orang yang dipimpinnya. Maka kualitas seorang pemimpin akan mempengaruhi maju atau mundurnya organisasi atau perusahaan. Peran seorang pemimpin dalam organisasi sangatlah vital, karena dalam perannya tersebut seorang pemimpin haruslah dapat mewujudkan visi dan misi organisasi atau perusahaan. 
Kepemimpinan (leadership) dapat dikatakan sebagai cara dari seorang pemimpin (leader) dalam mengarahkan, mendorong dan mengatur seluruh unsurunsur di dalam kelompok atau organisasinya untuk mencapai suatu tujuan organisasi yang diinginkan sehingga menghasilkan kinerja pegawai yang maksimal. Dengan meningkatnya kinerja pegawai berarti tercapainya hasil kerja seseorang atau pegawai dalam mewujudkan tujuan organisasi. Dilihat dari sudut pandang apapun juga pemimpin selalu ditempatkan pada satu titik yang sangat penting. Peran seorang pemimpin dalam satu organisasi atau kelompok sangatlah vital. Karena dalam perannya tersebut, seorang pemimpin akan membantu organisasi untuk mewujudkan visi dan misinya.

Oleh sebab itu, efektifitas seorang pemimpin di dalam menggunakan pengaruh-pengaruhnya sangat menentukan bagaimana pemimpin tersebut dapat memainkan perannya dengan baik. Untuk itu, pemimpin selalu harus diasah dan dikembangkan, sehingga dapat menyesuaikan diri dengan situasi-situasi yang dihadapinya. Baik situasi itu berasal dari anak buah, atasan ataupun organisasi di mana ia berada. Dapat dilihat disini pentingnya seorang pemimpin pada saat melaksanakan kepemimpinannya dapat memberdayakan dirinya sendiri sebelum memberdayakan orang lain.

PT. Bank Sinarmas, Tbk adalah salah satu Bank Swasta Nasional yang ada di Indonesia, termasuk berada di Propinsi Lampung. Di Lampung sendiri memiliki 8 Kantor Cabang Pembantu / KCP yang tersebar di beberapa Kabupten / Kota, salah satunya di Kota Metro. Bank Sinarmas KCP Metro sudah berdiri sejak tahun 2015. Sistem kerja Bank Sinarmas KCP Metro adalah mengutamakan pelayanan perbankan terhadap nasabah dan target penjualan perusahaan / KCP. Pelayanan perbankan terhadap nasabah dan target penjualan adalah hal yang selalu dibahas pimpinan kepada pegawainya. Pimpinan lebih sering marah dan memberi tekanan terhadap pegawainya apabila pelayanan terhadap nasabah kurang memuaskan dan target penjualan tidak tercapai.

Hal inilah yang sering membuat pegawai tertekan dan stres, sehingga pekerjaan tidak dapat terselesaikan dengan baik. Hal ini pula yang mempengaruhi penilaian pegawai terhadap pimpinannya menjadi kurang baik. Di dalam kepemimpinan seorang pemimpin harus mampu menjalankan kewajiban dan tanggung jawab dengan efektif dan efisien. Pemimpin tidak hanya memberikan perintah, memberi instruksi, memberikan hukuman, memberikan hadiah, mengancam, mengarahkan, tetapi lebih jauh dari itu peranannya. Sebagai pemimpin harus membawa dampak positif bagi para pegawai dan organisasi atau perusahaan.

Dalam hal ini penulis ingin meneliti dan mengkaji lebih lanjut mengenai kepemimpinan terhadap kinerja pegawai Bank Sinarmas KCP Metro. Selain kepemimpinan, di dalam sebuah perusahaan juga patut didukung oleh pegawai yang mempunyai kinerja yang baik sehingga tujuan perusahaan dapat terlaksana. Oleh karena itu pimpinan harus dapat mengatur para pegawai agar bekerja dengan baik serta bisa memotivasi pegawai. Berdasarkan halhal tersebut maka peneliti tertarik melakukan penelitian dengan judul: "Pengaruh Kepemimpinan Terhadap Kinerja Pegawai Bank Sinarmas KCP Metro".

\section{KAJIAN TEORI}

\section{Kepemimpinan}

Kepemimpinan didefinisikan ke dalam ciri individual, kebiasaan, cara mempengaruhi orang lain, interaksi, 
kedudukan dalam administrasi, dan persepsi mengenai pengaruh yang sah.

$$
\text { Menurut Pasolong }
$$
kepemimpinan adalah sebagai proses mengarahkan dan mempengaruhi aktivitasaktivitas yang ada hubungannya dengan pekerjaan para anggota kelompok. Menurut Veithzal Rivai (2010), kepemimpinan adalah proses mempengaruhi atau memberi contoh dari pemimpin kepada pengikutnya dalam upaya mencapai tujuan organisasi. Menurut Robbins \& Judge dalam Anoraga, (2011) menyebutkan bahwa kepemimpinan merupakan kemampuan untuk mempengaruhi suatu kelompok guna mencapai sebuah visi atau serangkaian tujuan yang ditetapkan. Menurut Stephen P. Robbins (2015), kepemimpinan merupakan kemampuan untuk mempengaruhi kelompok menuju tercapainya sasaran.

Berdasarkan beberapa pengertian menurut para ahli di atas, dapat ditarik kesimpulan bahwa kepemimpinan adalah suatu proses dimana seseorang mempengaruhi orang lain atau suatu kelompok dalam organisasi untuk mencapai tujuan tertentu. Adapun beberapa gaya yang dipakai oleh sesorang dalam memimpin bawahannya. Gaya kepemimpinan yang baik adalah suatu gaya yang dapat memaksimumkan produktivitas, kepuasan kerja, pertumbuhan, dan mudah menyesuaikan dengan segala situasi yang berkembang dan ada disekitar kita.

Menurut Veithzal Rivai (2010), gaya kepemimpinan adalah sekumpulan ciri yang digunakan pimpinan untuk mempengaruhi bawahan agar sasaran organisasi tercapai. Menurut Thoha dalam Pasolong (2010), gaya kepemimpinan adalah cara yang digunakan oleh seorang pemimpin dalam mempengaruhi bawahan agar mau melaksanakan tugas dan kewajibannya sesuai dengan yang diharapkan agar tercapai tujuan yang telah ditentukan sebelumnya.
Menurut Malayu. S. P Hasibuan (2013), gaya kepemimpinan adalah cara seorang pemimpin mempengaruhi perilaku bawahan, agar mau bekerja sama dan bekerja secara produktif untuk mencapai tujuan organisasi. Menurut Stephen P. Robbins (2015), gaya kepemimpinan adalah cara yang digunakan seseorang untuk mempengaruhi kelompok menuju tercapainya sasaran.

Berdasarkan beberapa pengertian gaya kepemimpinan dapat diambil kesimpulan bahwa gaya kepemimpinan adalah suatu cara yang digunakan oleh seorang pemimpin untuk mempengaruhi bawahannya untuk mencapai tujuan organisasi.

\section{Pengertian Kinerja}

Menurut Mangkunegara (2013), kinerja adalah hasil kerja secara kualitas dan kuantitas yang dicapai oleh seorang pegawai dalam melaksanakan tugasnya sesuai dengan tangggungjawab yang diberikan kepadanya. Simanjuntak (dalam Widyatmini, 2008) menyatakan bahwa kinerja perusahaan dan kinerja setiap orang juga sangat bergantung pada kemampuan manajerial atau pimpinan dalam membangun sistem kerja, membangun hubungan industrial yang harmonis, mengembangkan kompetensi pekerja, serta menumbuhkan motivasi dan memobilisasi seluruh karyawan sehingga dapat tercapai kinerja yang optimal.

Kinerja dibedakan menjadi 2 yaitu kinerja individu dan kinerja organisasi. Kinerja individu adalah hasil kerja karyawan baik dari segi kualitas maupun kuantitas berdasarkan standar kerja yang telah ditentukan, sedangkan kinerja organisasi adalah gabungan kinerja individu dengan kinerja kelompok. Mangkunegara (2009:75) mengemukakan bahwa pengukuran kinerja individu dilakukan 
melalui beberapa dimensi kinerja yaitu sebagai berikut :

1. Kualitas adalah seberapa baik seorang pegawai mengerjakan apa yang seharusnya dikerjakan. Kualitas dapat dilihat ketepatan kesesuaian dengan prosedur kerja yang ada.

2. Kuantitas adalah seberapa lama seorang pegawai bekerja dalam satu harinya. Kuantitas dapat dilihat dari kecepatan kerja setiap pegawai dalam penyelesaian pekerjaan.

3. Pelaksanaan tugas adalah seberapa jauh pegawai mampu melakukan pekerjaannya dengan akurat atau tidak ada kesalahan.

\section{Faktor-Faktor yang Mempengaruhi Kinerja}

Adapun faktor-faktor yang mempengaruhi kinerja seseorang menurut Hadari Nawawi (2015) adalah:

a. Faktor kemampuan, secara umum kemampuan ini terbagi menjadi 2 yaitu kemampuan potensi (IQ) dan kemampuan reality (knowledge dan skill).

b. Faktor motivasi, motivasi berbentuk dari sikap karyawan dalam menghadapi situasi kerja. Motivasi bagi karyawan sangat penting untuk mencapai visi dan misi perusahaan.

Menurut Mathis dan Jackson dalam Sinambela (2012) faktor- faktor yang mempengaruhi kinerja individu tenaga kerja yaitu :

a. Kemampuan mereka

b. Motivasi dukungan yang terima

c. Keberadaan pekerja yang mereka lakukan, dan

d. Hubungan mereka dengan organisasi
Sedangkan menurut Gibson dalam Handoko (2015) ada 3 (tiga) faktor yang berpengaruh terhadap kinerja yaitu sebagai berikut:

a. Faktor individu: kemampuan, keterampilan, latar belakang keluarga, pengalaman kerja, tingkat sosial dan demografi seseorang.

b. Faktor psikologis: persepsi, peran, sikap, kepribadian, motivasi dan kepuasan kerja.

c. Faktor organisasi: struktur organisasi, kepemimpinan, sistem penghargaan (reward).

\section{METODE PENELITIAN}

\section{Objek Penelitian}

Penelitian ini dilakukan di Bank Sinarmas KCP Metro, yang beralamatkan di Jl. Jenderal Sudirman No.872 Kelurahan Imopuro Kecamatan Metro Pusat, Kota Metro. Penelitian ini dilakukan selama bulan April - Juni 2018 di Kantor Bank Sinarmas KCP Metro. Dengan satuan penelitian pegawai tetap Bank Sinarmas KCP Metro.

\section{Metode dan Teknik Pengumpulan Data}

Metode pengumpulan data yang dimaksud pada penelitian ini adalah menggunakan data pribadi subjek dan alat pengukuran atau instrumen.

Dalam penelitian ini jenis data yang diperlakukan adalah :

a. Data Primer

Data primer merupakan data dasar yang akan diperoleh langsung tanpa perantara orang atau lembaga lain sebagai pihak ketiga. Data primer ini diperoleh dengan wawancara melalui responden dengan menggunakan daftar pertanyaan. 
b. Data Sekunder

Data skunder merupakan data yang diperoleh melalui orang lain yang berhubungan dengan permasalahan yang dipecahkan. Data sekunder ini diperoleh melalui cara studi dokumenter yaitu mengumpulkan dan mempelajari brosurbrosur serta dokumen organisasi.

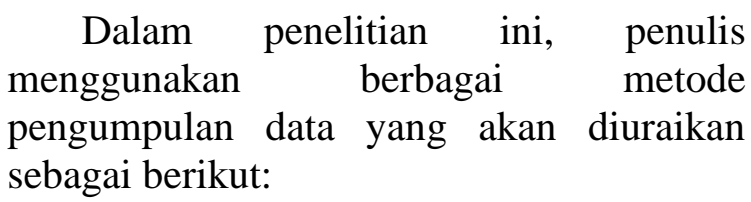

1. Observasi

Mengamati langsung fenomena yang berhubungan dengan variabel penelitian guna melengkapi data primer yang diperoleh melalui kuesiner.

2. Wawancara

Wawancara (interview) dilakukan dengan beberapa reponden yang dianggap perlu untuk memdapatkan penjelasan terlebih dahulu tentang penelitian ini yang dijumpai di lapangan penelitian.

\section{Kuesioner}

Daftar pertanyaan disebarkan secara tertutup dimana setiap pertanyaan sudah disediakan altenatif jawaban, sehingga responden hanya tinggal memilih salah satu alternatif jawaban yang dianggap sesuai kenyataan. Hal ini dimaksudkan untuk memperoleh data pendukung untuk memperkuat data hasil kueseoner.

\section{Studi Kepustakaan dan Dokumentasi}

Dilakukan dengan cara melihat dan mempelajari berbagai bahan bacaan, seperti buku-buku teoritis, makalah ilmiah, jurnal, dokumen dan laporanlaporan, temasuk barbagai peraturan yang berkaitan dengan variabel penelitian.

\section{Sampel dan Populasi}

Untuk menentukan populasi dan sampel Arikunto (2012) menyatakan ukuran minimum sampel untuk keperluan penelitian ini lebih dari 100 orang diambil sebanyak $10 \%$ dari jumlah keseluruhan populasi.

Berdasarkan penelitian ini karena jumlah populasinya tidak lebih besar dari 100 orang responden, maka penulis mengambil $100 \%$ jumlah populasi yang ada pada Bank Sinarmas KCP Metro yaitu sebanyak 30 orang pegawai yang bekerja aktif di bank tersebut. Populasi yang akan diteliti oleh penulis adalah responden yang secara kolektif dengan pengisian angket atau observasi, yaitu dengan mengambil sampel berdasarkan kegiatan atau dalam kondisi normal dan mau memberikan jawaban pada angket yang diberikan. Dalam peneilitian ini teknik sampel jenuh digunakan sebab jumlah populasi memenuhi standar statistika.

\section{Metode Analisis Data}

Untuk mengetahui tentang keabsahan instumen penelitian yang dianalisis, sebagai pegangan dari arti koefisien korelasi ( $r s$ ) adalah sebagaimana yang dikemukakan oleh Sekaran (2010) dalam bentuk uji validitas dan reliabilitas.

Untuk mengukur keeratan hubungan antara variabel Pengawasan (X) dengan variabel Motivasi (Y) digunakan koefisien korelasi, dengan menggunakan rumus Korelasi Product Momen sebagai berikut :

$$
r_{x y}=\frac{n \sum x y-\left(\sum x\right)\left(\sum y\right)}{\sqrt{\left[n \sum x^{2}-\left(\sum x\right)^{2}\right]\left[n \sum y^{2}-\left(\sum y\right)^{2}\right]}}
$$

$r \mathrm{xy}=$ koefisien korelasi $\mathrm{x}$ dan $\mathrm{y}$

$n \quad=$ jumlah sampel yang akan diuji

$x \quad=$ jumlah skor variabel

$y \quad=$ jumlah skor dari seluruh variabel 
Untuk mengetahui besarnya pengaruh, penghitungan koefisien korelasi tersebut kemudian dilanjutkan dengan Rumus Koefisien Determinasi atau Koefisien Penentu (KP):

$$
K P=(r)^{2} x 100 \%
$$

Untuk menguji secara hipotesis secara parsial digunakan Uji t dengan rumus :

$$
t_{\text {hitung }}=\frac{r \sqrt{N-2}}{\sqrt{1-r^{2}}}
$$

Keterangan:

$$
\begin{array}{ll}
\mathrm{t}_{\text {hitung }} & =\text { Nilai } \mathrm{t} \\
\mathrm{r} & =\text { Koefisien Korelasi } \\
\mathrm{N} & =\text { Jumlah responden }
\end{array}
$$

Kriteria untuk Uji $\mathrm{t}$ adalah sebagai berikut :

a) Jika $t_{\text {hitung }}>t_{\text {tabel }}$ maka Ha diterima dan Ho ditolak.

b) Jika $\mathrm{t}_{\text {hitung }} \leq \mathrm{t}_{\text {tabel }}$ maka Ha ditolak dan Ho diterima.

\section{HASIL DAN PEMBAHASAN}

\section{Uji Validitas dan Reliabilitas}

Hasil uji validitas (corrected item-total correlation) koefisien korelasi item pada variabel $\mathrm{X}$ dan $\mathrm{Y}$ seluruhnya valid. Sehingga pada uji reliabilitas semua item pernyataan variabel dilakukan uji. Hasil analisis uji reliabilitas yang terjadi menunjukkan bahwa kuesioner reliabel, karena skor alpha positif dengan nilai 0.823 dan lebih besar dari 0.6 Arikunto (2012). Dengan demikian dapat dikatakan kuesioner variabel $\mathrm{X}$ dan Y layak untuk digunakan dalam pengambilan data penelitian.

Setelah alat penelitian dinyatakan layak atau baik, dan dapat digunakan maka analisis dilanjutkan pada tahapan selanjutnya. Guna memudahkan dan pencapaian target analisis yang akurat, maka dalam operasional analisis data digunakan program statistika pengolahan data dalam penelitian ini responden berjumlah 30 responden sesuai dengan target.

\section{Analisis Kuantitatif}

Berdasarkan hasil uji, maka didapatkan persamaan model regresi yang sebagai berikut :

$$
\begin{array}{rll}
\mathrm{Y} & =8.468+ & 0.108 \mathrm{X} \\
\mathrm{t}_{\text {hitung }} & =(8.824) \\
\mathrm{R}^{2} & =0.736 \\
\mathrm{~N} & =30
\end{array}
$$

Dari hasil regresi yang telah didapat, maka dapat hasil penelitian dapat diinterpretasikan pada Uji t yang dilakukan untuk melihat besarnya pengaruh secara individu variabel bebas terhadap variabel tak bebas. Dan hasil estimasi dapat kita lihat bahwa nilai t hitung untuk variabel (X) sebesar 8.844 (Prob.sig. $=0,000$ ) yang berarti $\mathrm{t}$ hitung $>\mathrm{t}$ tabel dengan tingkat signifikansi 95\% (persen). Hal ini menunjukkan bahwa koefisien masing variabel bebas adalah penting secara statistik pengaruhnya terhadap variabel tak bebasnya atau dengan kata lain bahwa berpengaruh Signifikan.

Kemudian koefisien determinasi $\mathrm{X}-\mathrm{Y}$ $\left(\mathrm{R}^{2}\right)$ memiliki nilai yang besar yaitu sebesar 0.736 Berarti bahwa $73.6 \%$ (persen) dari variasi perubahan pengaruh Kepemimpinan dapat menjelaskan Kinerja. Sedangkan $26.4 \%$ (persen) sisanya adalah pengaruh dari variabel atau faktor-faktor lain diluar model.

Setelah dilakukan pengujian dan pembuktian hipotesis, selanjutnya dilakukan analisis untuk menguji hubungan butir terhadap variabelnya dan dilakukan pada setiap variabel uji guna mendapatkan hasil yang lebih detail pada setiap variabelnya dengan menggunakan metode 
rata - rata jawaban, Arikunto (2012). Pembahasan dari hasil rangkuman analisis tersebut maka gambar tersebut dapat diinterpretasikan bahwa Kepemimpinan memiliki pengaruh yang besar yaitu sebesar 73.6\% terhadap Kinerja pada Pegawai Bank Sinarmas KCP Metro.

Pada variabel Kepemimpinan juga didapatkan bahwa butir Atasan Anda memberikan penghargaan jika anda bekerja dengan baik dan benar memiliki kontribusi yang paling kecil. Kemudian Pada variabel Kinerja butir yang paling kecil adalah Tidak menyalahgunakan wewenang yang diberikan dalam menyelesaikan pekerjaan. Dari pengolahan data juga didapatkan bahwa masih ada variabel lain tetapi tidak begitu besar pengaruhnya yang belum dimasukkan tetapi memiliki pengaruh pada Kinerja sebesar $26.4 \%$.

\section{KESIMPULAN DAN SARAN}

\section{Kesimpulan}

Berdasarkan hasil analisis data maka didapatkan koefisien determinasi $\mathrm{X}-\mathrm{Y}$ $\left(\mathrm{R}^{2}\right)$ memiliki nilai yang besar yaitu sebesar 0.736 Berarti bahwa $73.6 \%$ (persen) dari variasi perubahan pengaruh Kepemimpinan dapat menjelaskan Kinerja yang berarti pengrauh kepemimpinan terhadap kinerja besar. Sedangkan $26.4 \%$ (persen) sisanya adalah pengaruh dari variabel atau faktor-faktor lain diluar model. Kemudian nilai t hitung untuk variabel (X1) sebesar 8.844 (Prob.sig. $=0,000)$ yang berarti t hitung > $\mathrm{t}$ tabel dengan tingkat signifikansi $95 \%$ (persen). Hal ini menunjukkan bahwa koefisien masing variabel bebas adalah penting secara statistik pengaruhnya terhadap variabel tak bebasnya atau dengan kata lain bahwa berpengaruh Signifikan. Hal ini dapat diartikan bahwa penelitian menolak Hipotesis $\mathrm{O}$ dan menerima Hipotesis Alternatif.

\section{Saran}

Saran yang dapat diberikan pada penelitian ini adalah sebagai berikut :

1. Sebaiknya pimpinan memberikan panduan dan arahan kepada pegawainya agar dapat bekerja lebih baik lagi.

2. Pimpinan memberikan target pekerjaan sesuai dengan standar target perusahaan yang harus dicapai pegawainya.

3. Sebaiknya pimpinan melakukan pengawasan pada pegawainya agar dapat bekerja sesuai dengan peraturan perusahaan dan tidak menyalahgunakan wewenangnya. Serta melakukan evaluasi hasil kinerja pegawainya yang telah dicapai.

4. Penghargaan adalah bentuk penilaian tinggi pimpinan terhadap pegawainya yang dapat diberikan berupa bonus, insentif ataupun promosi jabatan. Hal ini sangat penting agar pegawai merasa dihargai atas pencapaian kinerjanya yang memuaskan serta bisa menjadi motivasi untuk dapat bekerja lebih baik lagi.

5. Pimpinan sebaiknya memberikan arahan dan penjelasasan tentang wewenang apa saja yang dapat dilakukan pegawainya. Agar pegawainya tahu dan mengerti batasan-batasan wewenangnya supaya tidak melanggar peraturan perusahaan.

\section{DAFTAR PUSTAKA}

Arikunto, Suharsimi. 2012. Prosedur Penelitian-Suatu Pendekatan Praktek. Jakarta: Bina Aksara.

Deasler, Gary. 2016. Manajemen Sumber Daya Manusia. Jakrta: PT. Ghalia Indonesia. 
Effendy, Ondang Uchyana. 2014. Pengantar Manajemen. Bandung: Angkasa.

Flippo, Edwin B. 2015. Manajemen Sumber Daya Manusia. Jakarta: Bina Aksara.

Handoko, T. Hani. 2015. Manajemen Sumber Daya Manusia. Yogyakarta: BPFE.

Hasibuan, Malayu S.P. 2012. Manajemen Sumber Daya Manusia. Jakarta: Bumi Aksara.

Mangkunegara, Prabu. 2013. Manajemen Sumber Daya Manusia Perusahaan. cet. 2. Bandung: PT. Remaja Rosdakarya.

Manullang, M. 2012. Manajemen Personalia. Jakarta: PT. Ghalia Indonesia.

Martoyo, Susilo. 2010. Pengantar Manajemen Sumber Daya Manusia. Bandung: Penerbit Tarsito.

Nawawi, Hadari. 2006. Kepemimpinan Mengefektifkan Organisasi. Yogyakarta: Gajah Mada University Press.

Nitisesmito, Alex S. 2015. Manajemen Personalia. Jakarta: Penerbit PT Ghalia Indonesia.

Ranupandojo, Heidjrachman dan Suad, Husnan. 2010. Perilaku Organisasi. Bandung: Penerbit Angkasa.

Robbins, Stephen P. 2015. Organizational Behavior. New Jersey: Prentice Hall International.

Sekaran, Uma. 2010. Research Methods For Business. New York: John Wiley \& Sons, Inc.
Siagian, Sondang P. 2011. Manajemen Sumber Daya Manusia. Jakarta: Penerbit Gramedia.

Sinambela, Poltak. Lijan. 2012. Kinerja Pegawai Teori Pengukuran dan Implikasi. Yogyakarta: Graha Ilmu.

Sinungan, Muchdarsyah. 2017. Manajemen Personalia. Jakarta: Penerbit Ghalia Indonesia.

Sugiono. 2010. Metode Penelitian Pendidikan. Bandung: Penerbit Alfabeta.

Syadam, Gauzali. 2016. Manajemen Personalia Suatu Pendekatan Makro. Jakarta: Penerbit Djambatan. 